Iwona Mokwa-Tarnowska

Politechnika Gdańska

\title{
ASSESSMENT OF STUDENT LANGUAGE SKILLS IN AN E-LEARNING ENVIRONMENT
}

\begin{abstract}
SUMMARY
Assessment of student language skills in an e-learning environment

This article presents the role of various assessment structures that can be used in a VLE. e-Learning language courses offer tutors a wide range of traditional and computer-generated formative and summative assessment procedures and tools. They help to evaluate each student's progress, monitor their activities and provide varied support, which comes from the tutor, the course structure and materials as well as other participants. The format and ownership of procedures are also very important as they introduce variety, comprehensiveness and personalisation into assessment. Besides computer-generated feedback and tutor marking, also peer assessment and self-assessment play a significant role because they help students build confidence and develop analytical, critical-thinking and reflection skills, which result in them becoming self-directed learners in the future. The introduction of e-assessment into course design can have a number of positive effects, but it may also cause a number of serious concerns. If appropriately applied, technology used for delivering formative feedback and evaluating student progress in a summative way can enhance the quality of the learning process. However, if an e-learning course is overloaded with computer-generated tests, it will not engage students, and the dropout rate will be high.
\end{abstract}

Key words: e-learning, VLE, formative and summative assessment, language courses e-learning 


\section{STRESZCZENIE}

\section{Ocenianie umiejętności językowych studentów w środowisku e-learningowym}

Artykuł prezentuje rolę różnych struktur, służących do oceny pracy ucznia w wirtualnym środowisku edukacyjnym. Kursy e-learningowe oferują nauczycielom szeroki wachlarz procedur i narzędzi, które mogą oni wykorzystać do przeprowadzenia oceny formatywnej i sumatywnej w sposób tradycyjny i przy użyciu komputera. Pozwalają one na ocenianie postępów uczniów, monitorowanie ich aktywności oraz wprowadzanie różnych typów wsparcia ze strony nauczyciela, struktury kursu i materiałów, a także samych studentów. Zróżnicowane procedury oceniające oraz zaangażowanie uczniów w proces oceniania umożliwiają wielostronność i personalizację. Obok oceny dokonywanej przez system i nauczyciela, ważną rolę na kursie internetowym odgrywa współocenianie i samoocenianie, gdyż aktywności te pomagają studentom budować poczucie własnej wartości oraz rozwijać umiejętność myślenia analitycznego, krytycznego i refleksyjnego, dzięki którym mogą oni stać się uczniami samoregulacyjnymi. Wprowadzenie oceniania komputerowego może mieć liczne efekty pozytywne, ale może też być powodem wielu problemów. Właściwie wykorzystane technologie internetowe, użyte do oceniania formatywnego i sumatywnego, wpływają na podwyższenie jakości procesu edukacyjnego. Ogromna liczba testów wygenerowanych przez system może jednak zniechęcić studentów do pracy i stać się powodem wysokiego odsetka rezygnacji z uczęszczania na kurs.

Extensive and careful assessment whether traditional taking into account overall student performance and carried out in a classroom situation, or computer-supported made by the teacher on the basis of written assignments, exercises and exams or e-assessment of students' participation in e-learning programmes poses a great challenge for educators and course developers. Particularly the latter raises different questions because not only does its structure have to be carefully considered but also the way it is delivered is of crucial significance.

According to JISC', e-assessment is the end-to-end electronic assessment processes where ICT is used for the presentation of assessment activity, and the recording of responses. This includes the end-to-end assessment process from the perspective of learners, tutors, learning establishments, awarding bodies and regulators, and the general public'. Innovative methods are being adopted and new tools are being implemented to make assessment objective, thorough and balan-

$1 \quad$ JISC, Effective Practice with e-Assessment, 2007. 
ced as well as student-friendly and supportive. Different institutions are making every effort to develop evaluation techniques which could replace paper-based examinations in the future, and which will be more effective and more informative from the point of view of both educators and students - whether they can achieve success is yet to be seen.

An affective e-learning language course requires various evaluation structures. Learners' language skills can be assessed in many ways before an e-learning course, during it, at the end of each module and on completion of the whole course. During a diagnostic assessment process, which may take place on enrolment or prior to the commencement of a course for students whose level ranges from intermediate to advanced, e.g., in Technical Writing in English, students' general knowledge of the language can be tested, especially if it is not known to the staff. During the process tutors should definitely check if course participants know basic linguistic terminology, which they will need to understand task instructions, which ought to be in English, and if they are able to use essential language structures, which they will need to proceed with genuine and simulated writing ${ }^{2}$. Such testing will not be necessary if course participants attend other language programmes at the same time or if e-learning is a component of a blended course ${ }^{3}$ they have earlier joined.

Formative ${ }^{4}$ assessment, which provides learners with feedback on their progress, which enriches their understanding of the subject matter, and which shows them how well they have been able to meet course aims and objectives is frequently referred to as 'assessment for learning ${ }^{5}$. In order for it to be effective, it has to be provided throughout the whole course. The focus on its developmental role is what makes it student-centred and student-friendly. What is more, being assessed in a formative way, students get gradually accustomed to assessment practice, which they will find very supportive when they understand that its purpose is to speed up the learning process.

2 A comparison between simulated and genuine writing is presented by R. Wenzel in The Education of a Language Teacher, Gdańsk 2001, pp. 96-107.

3 I. Mokwa-Tarnowska, Blended Learning in a Digital Age, [in:] II International Language Conference: Employee Empowerment, Learning Foreign Languages in a Corporate Environment, M. Chomicz and K. Paszkowski (eds.), Warszawa 2009.

4 B. Cowie and B. Bell, A Model of Formative Assessment in Science Education „Assessment in Education" 1999, 6, 101-116; T. Crooks, The Validity of Formative Assessments, Paper presented to the British Educational Research Association Annual Conference, University of Leeds, 13-15 September 2001, http://www.leeds.ac.uk/educol/documents/00001862.htm [accessed 20 September 2013].

5 JISC, Effective Practice with e-Assessment, 2007, 6; M-N. Lamy and R. Hampel, Online Communication in Language Learning and Teaching, Basingstoke 2007, p. 91. 
Summative assessment ${ }^{6}$, which is sometimes described as assessment of learning ${ }^{7}$, can be carried out at the end of each module to show students how well they have developed new knowledge or skills. Its purpose is also to provide the tutor and course participants with the information whether some more difficult issues still need explaining, analysing or practising. Finally, summative assessment done at the end of each module shows which students may start working on the next section, which have to retake the-end-of-the module test or which need further practice or assistance to be able to successfully complete the module. On completion of the whole e-learning programme, student progress may be evaluated once again by means of a test. For example, in the case of courses that focus on developing the writing skill such as Technical Writing or Academic Writing this is not necessary because in order to pass each module, students should be required to submit a long tutor-marked assignment, which being either genuine or simulated writing will provide a more comprehensive picture of student's progress and achievements. Provided students have passed every module, they can pass the whole course on the basis of their aggregate marks. However, more extensive tests or detailed examinations can be given to learners who have studied language areas such as vocabulary and grammar, and linguistic theories or who have tried to upgrade all their skills during a general English course and an ESP course.

Both formative and summative assessment of participants of a tutor-supervised e-learning course can be conducted in different ways, either traditionally or using tools available in an e-learning environment. Whichever method will be used depends on the tutor's preferences, course objectives and the type of skills and knowledge that the course is structured around. Neither method is better than the other because their nature is different. They should supplement each other. The ratio between traditional methods and e-assessment methods must also depend on the structure of an e-learning programme, the environment, that is, the management system which supports the course, and the availability of an appropriately equipped classroom in the case of exams and final tests. It can change over time during the coursework. However, it should be stressed that traditional assessment made by the teacher, especially the formative one, is more studentfriendly. The educator can always personalise their assessment procedures. Thus, it is more in keeping with the student-centred approach. Moreover, students who

6 D. Scott, Curriculum Studies: Boundaries: Subjects, Assessment, and Evaluation, New York 2003, http://books.google.com/books?id=llc8VhacrD8C\&pg=PA203\&dq=summative+assessment\&cd $=3 \# \mathrm{v}=$ onepage $\& \mathrm{q}=$ summative $\% 20$ assessment $\& \mathrm{f}=$ false [accessed 6 November 2013]; J. M. Atkin, P. Black and J. Coffey (eds.), Classroom Assessment and the National Science Education Standards / Committee on Classroom Assessment and the National Science Education Standards, Washington 2005.

7 JISC, op. cit. 
sit examinations that include open questions can expand on their answers, which enables them to present more language structures in context and a thorough understanding of the problem in a more natural way, which in turn is very much in line with constructivism ${ }^{8}$. Computer-based assessment on language courses is of limited usage as teachers or course developers have to foresee the correct answers to their multiple-choice quizzes, cloze tests or matching exercises, and enter their feedback into the system in the design phase. Delivering such final tests or exams, they are able to check only a small fraction of issues covered by the course. As a result, the assessment of student progress is definitely inconclusive. In the constructivist paradigm, which underlies learning and teaching in an e-learning environment, particularly in a virtual learning environment (VLE) ${ }^{9}$, students should be encouraged to construct meaning through writing texts that show in-depth analyses based on the acquired knowledge and skills.

The format and ownership of procedures are also very important as they introduce variety, comprehensiveness and personalisation into assessment. If appropriately applied, technology used for delivering formative feedback and evaluating student progress in a summative way can enhance the quality of the learning process. Educators who want to apply e-assessment solutions first have to carefully analyse assessment needs of the students who will participate in the e-learning programme, the tutors who will monitor student work in the virtual classroom, and the award granting body. They should also consider the nature of the subject itself. Then they must adapt assessment techniques to their findings, and decide in which subject areas they can be applied or where they should not replace traditional evaluation methods. Next they ought to analyse which techniques are the best and most powerful of those available or of those that can be easily developed or purchased. New ways of evaluating student work and progress during an e-learning course can be effective only if all the above mentioned factors are taken into account. It is not worth experimenting with e-assessment if tutor marking, because of its value and quality, has proven to be effective.

Both formative and end-of-the module summative assessment in an online course such as Technical Writing in English or Academic Writing or English for

8 A. Jordan, O. Carlile and A. Stack, Approaches to Learning: A Guide for Teachers, Meidenhead 2008, pp. 55-62; J. Piaget, Mechanisms of Perception, New York 1969; J. Bruner, Toward a Theory of Instruction, Cambridge, MA. 1966; E. von Glasersfeld, Radical Constructivism, New York 1995; L. S. Vygotsky, Mind in Society, M. Cole, V. John-Steiner, S. Scribner and E. Souberman (eds.), Cambridge, MA 1978.

9 A virtual learning environment is a course management system, which provides the developer and tutor with a number of tools to foster different types of communication and interaction between the tutor and the students, and between and among the students themselves. Moodle, an open source system, is gaining in popularity in Poland and across the academic world. 
Mechanical Engineers can be traditional. The former can be delivered by the tutor when they see that students struggle with some language structures and vocabulary items which they do not know or which they find difficult to correctly use, or when they realise that learners have problems applying text structure constraints within a given genre. Formative feedback may be sent to students via email, it may also be provided during chats or online discussions carried out in the virtual classroom. It may have the form of comments, remarks, suggestions, advice, requests, reflection points, analysis or descriptive evaluation. Traditional summative assessment which evaluates students' ability to produce a text must be done in writing. The tutor should send their feedback written in an electronic format, e.g., in a .DOC file directly to the student, and they should also post some general comments together with the mark for the assignment to the course website, that is, they should place it in the appropriate section, e.g., called the Gradebook. In a VLE such as Moodle, both the comment and mark are only visible to the tutor and the student who has written the work.

Computer-based assessment, that is, e-assessment, both diagnostic, formative and summative, can be very effective if it is delivered in the form of a multiple-choice test with randomised question selection. Such a format allows for the objective evaluation of student progress and achievements. However, it cannot be used to test the understanding of any subject or any topic. Nowadays it is often applied to evaluate the knowledge of students of law, medicine, life sciences, nursing and languages ${ }^{10}$, that is, the knowledge which involves memorising a vast number of facts, data and other detailed information. In the case of languages, the mastery in the use of vocabulary items or some grammar structures, obviously only in the contexts in which their occurrence is unambiguous, can be tested by multiple-choice questions delivered online. Computer-based tests which check the knowledge of students of science and technology are more difficult to develop. When learners apply critical thinking skills and analytical skills to problem solving, not only the right answer but also the way they have reached it are important. This means that the stages of reasoning students have gone through are equally significant and should be evaluated. In such a case tutor marking is indispensable, and cannot be replaced with e-assessment.

Another important thing is that e-learning quizzes, which include multiple choice, true/false and matching questions, should be set up so that they will discourage students from cheating, and so that they will engage them in learning. Because the tool used to develop them has a lot of settings, which can be edited any time, it is easy to achieve the most useful effects. For example, students can

10 JISC, op. cit., p. 22. 
see their grades or correct answers or both at a specified time, that is, during the attempt or after it when the quiz is still open or when the quiz has been finished and submitted to the system or when the quiz is closed and cannot be any longer approached by students. The system can also randomly choose questions from a prepared bank, and each student can get a different set. It is also advisable to allow the course management system to change the order in which the selected questions are displayed within the test if the order is not important. However, if the test has to be done sequentially and each question is related to the previous one or if the next question can be accessed only after the previous one has been correctly answered, the order in which questions were entered should be preserved. Another thing is that too many items in one quiz can deter learners from doing it carefully, and can disturb their concentration. This may result in them clicking on any answer that seems right, and going through the quiz as fast as possible. Feedback obtained in this way is much less constructive than if it was based on a tutor-marked exercise with open questions. The score stored in the system does not provide the tutor with much information either. All things considered, the tutor should not assess students' newly acquired knowledge and skills only on the basis of their performance in computer-generated quizzes. However, if they are well-designed, they can be a valuable source of information about progress rate. The inclusion of a great number of quizzes of this kind in the course means excessive and unnecessary workload. Instead of being an engaging activity, they can become a hindrance for learning.

During an online course in general English or English for Specific Purposes or a course in literature or linguistics, tutors can adopt different assessment procedures, which can be used to evaluate tests, examinations, case studies, projects, e-portfolios, papers, tasks, exercises and answers to open questions. Besides computer-generated feedback and tutor marking, also peer assessment and self-assessment play a significant role ${ }^{11}$, as they help students build confidence and develop analytical, critical-thinking and reflection skills, which will result in them becoming self-directed learners in the future ${ }^{12}$. The shift in the ownership of assessment procedures from only teacher-based to student-based can lead to greater student engagement in the learning process and better learning outcomes $^{13}$. The focus on creating a proper environment for active learner participation in course activities is especially important when e-learning is taken into account, as inactivity, often caused by the lack of interest and engaging tasks, leads to a high

11 M-N. Lamy and R. Hampel, op. cit., p. 96.

12 C. Burke, What is Critical Thinking? 2003. http://critthinking.weebly.com/week-1-what-is-criticalthinking.html [accessed: 20 September 2013].

13 A. Jordan, O. Carlile and A. Stack, op. cit., p. 65. 
drop-out rate. Various tools available to both tutors and students in a VLE that allow creating social space, e.g. discussion forum, wiki, chat, workshop, can be used for assessing knowledge, skills and performance, and to introduce different assessment procedures.

During the course students have to perform different tasks, on the basis of which they can be assessed. At the beginning, in order to engage them in the learning process, the tutor should encourage the participants to familiarize themselves with the environment. This can be achieved by assigning a short self-introduction task, which can be placed either on a discussion forum or in the Blog section or in the file labelled 'Notes', all of which are an inherent part of a virtual learning environment. Students can be asked to introduce themselves by writing a few sentences about their professional interests ${ }^{14}$. This results in the participants feeling less isolated - a very common feeling which working from home via the Internet evokes. By learning about one another's interests and goals, students are more likely to perceive themselves to be members of a classroom community. Thus, online learning will take place in a more natural environment. Besides, the tutor

14 During her one-semester online courses in Technical Writing developed in Moodle, the author always asks her students to introduce themselves, and treats the task as the first assignment. The learners are asked to write a few sentences about themselves. To make it easier, those who do not know what information to include are advised to answer the following questions: 'What do you study and why?', 'What are your professional interests?', Why did you decide to join the course?'. Because there is no kick-off workshop prior to the commencement of the course, the tutor thinks that by introducing themselves in this way, the students will be able to find out more about one another. The assignment is always posted to the general discussion board. It includes instructions how to write a short self-introduction, and a request to submit it via the forum. Thus, every post can reach every participant as well as the tutor - the Moodle system not only displays it on the general discussion forum but also sends it to the learners' private email accounts. Due to this assignment, the tutor always learns more about the writing skills of the enrolled students. No suggestions as to the style or length of the answers are given. The results are always similar. Most of the students can produce a coherent text, fairly informative and written to the point. All of them make various mistakes, mostly structural. They use wrong tenses, wrong prepositions and sometimes inadequate vocabulary. They sometimes struggle with the correct word order, and subordinate clauses lack the proper structure. The students have also problems using articles, sometimes in simple contexts. However, on the whole, a great number of the texts are always relatively well written. By completing this assignment, the participants learn something about one another, and they understand that they are part of a cohort group. They are no longer names on the list, but real students who are on the same course. The task allows the tutor to get to know her learners, their interests and expectations, as well as some of their language problems. The tutor has decided not to evaluate the introductory assignment in order not to discourage the students. They could feel inhibited if they saw how many mistakes they made. The most frequently made mistakes - some phrases wrongly translated from Polish into English which the students may need to write their CVs or covering letters - are regularly used by the tutor to prepare a final quiz, which aims at teaching and not testing. For details see: I. Mokwa-Tarnowska, Student Activity in an e-Learning Environment, [in:] Modern Approaches to LSP: Selected Issues in Teaching Adults at Higher Educational Level, L. Szczuka-Dorna (ed.), Poznań 2013. 
can assess the general writing skills of the participants, if their language competence in this respect was not identified earlier, and can update the content of the course to meet the needs of the students as well as introduce responsive support structures ${ }^{15}$. e-Learners.com ${ }^{16}$ also advises online students to write about their hobbies and interests in their bio page, to find somebody in the cohort they could make friends with, to regularly visit the course and take part in all discussions and chats, to communicate with other students as frequently as possible and to look for different opportunities to meet fellow students as well as to get in touch with the tutor via e-mail whenever they need some advice or if they want to share information. On the one hand all the above mentioned activities engage students and motivate them to work efficiently in an e-learning environment, on the other hand they create numerous possibilities to carry out an assessment of a number of skills, both language, analytical, critical-thinking and reflective.

e-Learning courses should promote student self-assessment. VLEs have many tools, which enable developers to create various resources, that is, more static educational materials. It must be emphasized that they should not be composed of long informative and explanatory texts, because such materials will not engage students, who will immediately lose interest if the resource they are reading is only packed with information in the form of running text. In order to keep students focused, every webpage with a lot of information should include different tasks that break up the text, self-assessment points being one of them. Short questions concerning what the student has just read show them what is important and what should be remembered. They also stimulate self-reflection, teach how to approach problems and encourage an in-depth analysis. Answers to such tasks can be provided on the same webpage or in a special file uploaded in the location specified in the instructions or in the syllabus or linked to an icon on the main page. They may not be given at all. In that case, students must be informed that they can write their reflections and responses, if they like to do so, and upload them to the course website for tutor's formative assessment.

Learners can benefit from an e-learning programme if the system of student support is well-defined and explained at the beginning of the course. If they know how to help others, they will more eagerly provide support; on the other hand if those who need advice are familiar with the course policy towards encouraging peer support, they will seek it and accept it. The best way to change students'

15 I. Mokwa-Tarnowska, Support Mechanisms in Teaching Technical Writing in the Online Environment, [in:] International Language Teaching Conference: Seeking Most Effective Methods at Different Levels - Organisation, Methodology, Tools, M. Chomicz and B. Trela (eds.), Warszawa 2008.

16 e-Learners.com, How to Avoid Feeling Isolated in Your Online Class, http://www.elearners.com/ online-education-resources/online-learning/how-to-avoid-feeling-isolated-in-your-online-class/ [accessed: 20 September 2013]. 
attitude is to introduce peer review ${ }^{17}$. Before the task, the tutor must define what aspects students have to take into account and how to assess them when evaluating writings and projects of their classmates. They should prepare a set of clear instructions on how to give advice to other group members, and how to assess their works. In some VLEs there are tools which allow designing such an activity. For example, in Moodle the tutor can use the tool called 'workshop'. The system automatically sends submitted assignments to the specified number of reviewers, who after fulfilling the task upload their feedback for the tutor's acceptance. If the tutor decides that it meets the required standard, they pass it on to the reviewee by clicking on the appropriate icon. If the procedures are straightforward, students will treat peer assessment as another activity which involves analysing, commenting and writing.

The assessment of students' progress carried out during the course allows the tutor to modify the existent support structures and introduce new ones. Additional exercises and tasks should be uploaded to the course webpages if the participants struggle with vocabulary, grammar, cohesion, coherence or the understanding of the content of the resources. After correcting submitted assignments and sending their feedback to the students, the tutor must decide whether to add some activities to the course content, and whether to make them available to all the participants or only to some. They can label new additions as optional, and target both those students who feel the need to improve their skills because they are insufficient, and those who want to test and assess their language competence. The tutor can monitor and evaluate each student's progress by accessing appropriate logs and checking what they have read, which quizzes they have started and which they have completed, what mistakes they have made, and how many times they had approached a certain question until they found the correct answer. If the tutor notices any problem areas, they can easily change the content, add new quizzes, provide additional tasks or start a new discussion on possible solutions. They can personalize their support and concentrate on individual needs. The purpose of at least some quizzes developed in a VLE should be to teach students and not to test them. This means that learners must be allowed to attempt them as many times as they want. The tutor can always change the settings, and may decide not to show the correct answers until, e.g., the last week of the coursework finishes. However, students must be informed in advance when they are supposed to be displayed.

17 Maija Tammelin a former lecturer in the Department of Languages and Communication at Helsinki School of Economics (now Aalto University School of Business) has successfully introduced peer review of reports to the online courses in Academic Writing she has developed. Before the task, her students were given a list of questions they had to answer when reading other group members' assignments. Then the comments were checked by the tutor and sent to the author of the report, who was supposed to incorporate them into the final version to be submitted for tutor assessment. 
A new approach to assessment methods can be seen in an increasing popularity of e-portfolios ${ }^{18}$. Using this tool, students can present the knowledge they have gained, skills they have acquired and self-reflection abilities they have developed. They can show how they have matured over a period of time, and how much their knowledge has increased. They can submit their e-portfolios, which are being constructed throughout the whole learning process, for assessment and validation whenever the tutor needs them or when they want them to be reviewed. The difference between this evaluation method and more traditional ones lies in the degree of personalisation. e-Portfolios enable students to choose what they want to present, and how they want to present the learning outcomes, thus not only the content but also the skills necessary to use this tool may be assessed. What is more, a student's development over a period of time can be seen. Using e-portfolios with students attending language, literature and linguistics courses or any other classes during which learners develop their language skills can bring positive effects if the tutor manages to encourage their students to upload regular entries. This can be achieved by asking course participants to record answers to reflective tasks or points, included in the reading resources to increase student engagement and concentration. The production of entries in e-portfolios should be regarded as an additional activity whose purpose is to develop students' writing, analytical and reflective skills.

There are various advantages of introducing e-assessment into course design. Feedback is instantaneous, which is especially important in the case of formative assessment, which supports students throughout the learning process. On-demand diagnostic testing speeds up enrolment procedures, and on-demand formative testing can quickly identify problem areas. Computer-based assessment can also help to manage an increasing number of students, whose works would otherwise have to be examined by a lot of staff. The results delivered by computer software are objective and accurate. The course management system can also track down students whose performance exceeds expectations, and those who are lagging behind. As a result, the tutor can immediately provide the weak with additional tasks and support, and the most brilliant ones with more challenging tasks and more difficult problems. Finally, e-assessment can offer a better testing environment for students with physical disabilities, who

18 Although an e-portfolio is still an innovative tool, it has been in use as an assessment method in a number of vocational programmes. The BA (Hons.) Learning through Technology degree course at Ultraversity, Anglia Ruskin University, is offered entirely online. Students use an e-learning platform to collaborate with one another and access course resources. They record their achievements, learning outcomes and the progress in understanding important issues in e-portfolios, they can also decide whether to upload their productions for peer review. See: Anglia Ruskin University, http:// www.ultraversity.net/ [accessed 20 September 2013]; JISC, op. cit., p. 32. 
may feel more comfortable sitting an exam delivered in an easy to use electronic format.

Introducing e-assessment may cause a great number of serious concerns. Firstly, remedial procedures in case of computer failure during a test or exam which aims to measure progress and achievements and which students take on the campus have to be developed. Which means that back-up systems need to be designed in order to recover lost data. Secondly, testing should be carried out in an environment in which there are reliable tools allowing for the authentication of the user. Thirdly, to avoid plagiarism, students' work during an exam has to be monitored by means of special software ${ }^{19}$. Fourthly, the quality of question design is extremely important. Educators must develop such questions to which answers are straight and precise. Only these responses typed in by students during a test or examination which exactly match the ones uploaded earlier to the system by the staff will be recognised by the system as correct. If a question requires a complex answer, it is highly unlikely that all accurate options can be predicted by course developers. Thus, even good answers can be regarded by the system as wrong if these wordings have not been stored. What is more, inaccuracies in spelling cause that a correct answer with some spelling errors is always treated by the system as incorrect. All answers in a VLE such as Moodle have to be carefully introduced by the developer, and students must be warned that even a double space instead of a single one in between, e.g., words is regarded by the system as a mistake. For example, at University of Manchester possible spelling problems that students can have during online examinations have been addressed by adding a subjectspecific word list of 1500 terms stored in an HTML file, uploaded to the WebCT environment ${ }^{20}$, in which tests are developed at this university. Students choose the right term from the list, and paste it into the dialogue window ${ }^{21}$. To conclude, ineffective question and task design can undermine the whole idea of e-assessment.

Frequent assessment provides feedback and enhances the learning process. Course developers and decision makers have to decide what form it should have,

19 Farnborough Sixth Form College, one of Britain's top sixth form colleges, has overcome the problem of plagiarism by installing a plagiarism detecting tool which monitors student activity during an exam. It takes screenshots and shows data transmission paths if necessary. The information it records is kept in a secure place, and can be retrieved if cheating is suspected. The existence of this tool has so far acted as a deterrent The college also uses privacy screen filters, which do not allow students to read what is on other screens as they appear black when viewed at an angle. See: JISC, op. cit., p. 21; The Sixth Form College Farnborough, the. http://www.farnborough.ac.uk/ [accessed: 20 September 2013]. When students at Reid Kerr College (now West College Scotland), sit an exam, questions on their screens are randomized, no case of cheating has been registered there.

$20 \mathrm{WebCT}$ is a proprietary virtual learning environment, developed at the University of British Columbia.

21 For details see: JISC, op. cit., p. 29. 
whether traditional or electronic. If they choose e-assessment, they must realise that its inclusion in the learning design can have serious implications for education. Staff and students need to be trained how to approach computer-based tests. Money has to be invested in applying the best possible software to quarantine the quality of assessment procedures ${ }^{22}$. Moreover, tutors should understand that e-assessment is not only a way of evaluating students' progress and achievements but it is also a means of identifying various problems learners cope with during an online course. Due to it, educators can immediately support their students helping them to engage effectively in course activities. This will result in them meeting course aims and objectives, and becoming more proficient users of the language they are learning as well as better self-directed learners.

\section{Bibliography}

Anglia Ruskin University, 2010, http://www.ultraversity.net/ [accessed: 20 September 2013].

Atkin J. M., P. Black and J. Coffey (eds.), Classroom Assessment and the National Science Education Standards / Committee on Classroom Assessment and the National Science Education Standards, Washington 2005.

Bruner J., Toward a Theory of Instruction, Cambridge, MA 1966.

Burke C., What is Critical Thinking? http://critthinking.weebly.com/week-1-what-is-criticalthinking.html [accessed: 20 September 2013].

Cowie B. and B. Bell, A Model of Formative Assessment in Science Education. „Assessment in Education" 1999, no. 6.

Crooks T., The Validity of Formative Assessment, Paper presented to the British Educational Research Association Annual Conference, University of Leeds, 13-15 September 2001, http://www.leeds.ac.uk/educol/documents/00001862.htm [accessed: 20 September 2013].

e-Learners.com, How to Avoid Feeling Isolated in Your Online Class, 2010. http://www.elearners. com/online-education-resources/online-learning/how-to-avoid-feeling-isolated-inyour-online-class/ [accessed: 20 September 2013].

Glasersfeld E., von, Radical Constructivism, New York 1995.

JISC, Effective Practice with e-Assessment, 2007.

Jordan A., O. Carlile and A. Stack, Approaches to Learning: A Guide for Teachers, Meidenhead 2008.

Mokwa-Tarnowska I., Support Mechanisms in Teaching Technical Writing in the Online Environment, [in:] International Language Teaching Conference: Seeking Most Effective Methods at Different Levels - Organisation, Methodology, Tools, M. Chomicz and B. Trela (eds.), Warszawa 2008.

22 'People often talk about the cost of e-learning, which is the wrong attitude. It is about value and what it brings to the institution. The people cost is substantial, but a good investment', - comments Richard Parsons, Director of e-Learning at Dundee. See: Ibidem, p. 23. 
Mokwa-Tarnowska I., Blended Learning in a Digital Age, [in:] II International Language Conference: Employee Empowerment: Learning Foreign Languages in a Corporate Environment, M. Chomicz and K. Paszkowski (eds.), Warszawa 2009.

Mokwa-Tarnowska I., Student Activity in an e-Learning Environment, [in:] Modern Approaches to LSP: Selected Issues in Teaching Adults at Higher Educational Level, L. Szczuka-Dorna (ed.), Poznań 2013.

Piaget J., Mechanisms of Perception, New York 1969.

Scott D., Curriculum Studies: Boundaries: Subjects, Assessment, and Evaluation, New York 2003, http://books.google.com/books?id=llc8VhacrD8C\&pg=PA203\&dq=summative +assessment\&cd=3\#v=onepage \&q=summative\%20assessment $\& \mathrm{f}=$ false [accessed: 6 November 2013].

Sixth Form College Farnborough, the, 2010, http://www.farnborough.ac.uk/ [accessed: 20 September 2013].

Vygotsky L.S., Mind in Society, M. Cole, V. John-Steiner, S. Scribner and E. Souberman (eds), Cambridge, MA 1978.

Wenzel R., The Education of a Language Teacher, Gdańsk 2001. 